Please reference as

Darcy, S. (2003). The politics of disability and access: The Sydney 2000

Games experience. Disability \& Society, 18(6), 737-757.

\title{
The Politics of Disability and Access: the Sydney 2000 Games Experience
}

\author{
Simon Darcy \\ Senior Lecturer \\ School of Leisure, Sport and Tourism \\ Faculty of Business \\ University of Technology, Sydney \\ PO Box 222 \\ Lindfield NSW 2084 \\ Tel: 612 9514-5100 Fax: 612 9514-5195 \\ Email: Simon.Darcy@uts.edu.au
}

The paper examines disability and access issues surrounding the Sydney 2000 Olympic and Paralympic Games. Central to this is an examination of the involvement of the Australian community of people with disabilities ${ }^{1}$ within the Games. The Sydney Paralympic Games in particular, was seen as a possible watershed event for developing accessible infrastructure and raising awareness of disability and access issues. This paper draws on the official documents of the Games, newspaper accounts and disability organisation reports. The paper firstly examined the major bodies charged with organising the Games and the planning processes used to incorporate disability and access issues. The paper then examined a range of critical issues and their relationships with the disability community. Lastly, the paper provided an analysis of any likely legacies that the 2000 Games may have for Sydney's community of people with disabilities.

\section{BIO NOTE}

Simon Darcy is a Senior Lecturer in the School of Leisure, Sport and Tourism at the University of Technology, Sydney. He teaches, researches and has published in the areas of leisure and tourism participation patterns, public policy, environmental planning, and inclusive planning practices for marginalised groups. Since incurring a spinal cord injury Simon is a power wheelchair user and has been active in the advocacy and research of issues facing people with disabilities.

\footnotetext{
${ }^{1}$ The person first terminology of people with disabilities is the preferred usage in the Australian context (Hume 1994). This paper uses the person first terminology but recognises the political strategy of using the term disabled people as a signifier of the disabling nature of society that produces disabled people (Oliver 1990).
} 


\section{INTRODUCTION}

The conventional wisdom is that the Paralympic Games brings the host city community of people with disabilities an opportunity for a lasting legacy of accessible infrastructure, a raised level of disability awareness and an improved position in society (Davis 1996; Higson 2000). This paper evaluates the level and extent of this assumption in relation to the Sydney 2000 Games from a disability perspective. Were there changes attributable to the Games that has improved the position of people with disabilities in Sydney, New South Wales (NSW) or Australia? The Sydney 2000 Games occurred over three months and included the Olympics, Paralympics and the Cultural Olympiad that surrounds both events. The areas of investigation include critical issues to hosting the Games, broader disability representation in the Games, the relationships established with the disability community and the likelihood of a lasting legacy. This paper draws on the official documents of the Games, newspaper accounts, disability organisation reports and personal communications. The paper does not examine the broader issues of disability advocacy, politics or new social movements in Australia as these have been examined elsewhere (Newell 1996; 1999; Cooper 1999).

\section{BACKGROUND}

Sydney is a sprawling urban metropolis of some 4 million people (Australian Bureau of Statistics 2000). There are well-documented environmental, social and attitudinal barriers faced by people with disabilities in Sydney (Physical Disability Council of NSW 1999a). Figure 1 shows that the Sydney 2000 Games occurred in some 14 
separate precincts covering approximately $70 \mathrm{~km}$ from East to West as well as soccer matches in four other inter state locations (SOCOG 2000a). The main Games precinct where most of the venues were located was Homebush Bay.

Figure 1: Geographic Spread of Venues in Sydney

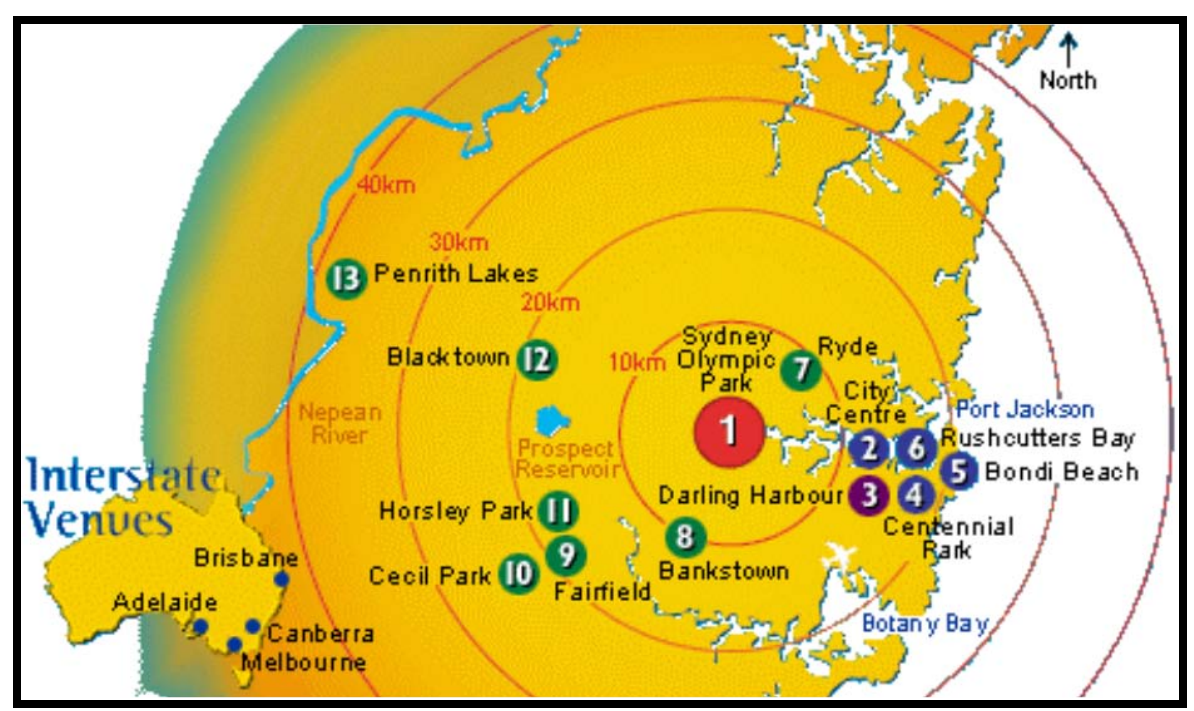

Source: SOCOG 2000

The paper will not review the logistics of staging the Sydney 2000 Games as this has been completed elsewhere (A. Hughes 1999a; SPOC 1999a; SOCOG 2000a). However, for this section there was a need to have some understanding of the organisational responsibilities for planning, designing, developing and operationalising the Games as it was the approach to disability and access of these organisations that impacted on the effectiveness of the outcomes from a disability perspective. There were four main organisations charged with the planning of the Games. Table I presents their name, acronym and role: 
Table I: Games Planning Agencies

\begin{tabular}{|c|c|c|}
\hline Organisation & Acronym & Role \\
\hline $\begin{array}{l}\text { Sydney Organising Committee for the } \\
\text { Olympic Games }\end{array}$ & SOCOG & $\begin{array}{l}\text { - Staging of the Olympic and Paralympic Games, and the Olympic } \\
\text { and Paralympic Cultural Olympiads } \\
\text { Http://www.sydney.olympics.org/eng/ }\end{array}$ \\
\hline $\begin{array}{l}\text { Sydney Paralympic Organising } \\
\text { Committee }\end{array}$ & SPOC & $\begin{array}{l}\text { - } \quad \text { SPOC is charged with the staging of the Paralympic Games } \\
\text { - } \quad \text { SOCOG and SPOC entered into an Operational Partnership }\end{array}$ \\
\hline & & $\begin{array}{l}\text { whereby the Paralympic programs (sporting competition, volunteers, } \\
\text { venue management, medical, security, accommodation, arts festivals, } \\
\text { marketing programs etc.) will be delivered by SOCOG (SPOC 1999:6) }\end{array}$ \\
\hline Olympic Co-ordination Authority & OCA & $\begin{array}{l}\text { Planning, design and development of venues; } \\
\text { - } \quad \text { operation of sites during Games; } \\
\text { - } \quad \text { co-ordination across agencies (OCA 1999). } \\
\text { Http://www.oca.nsw.gov.au/ }\end{array}$ \\
\hline Olympic Roads and Transport Authority & ORTA & $\begin{array}{l}\text { - } \quad \text { planning and co-ordinating transport services during the Olympics } \\
\text { and Paralympics; } \\
\text { - } \quad \text { travel demand management; and } \\
\text { - maintenance of existing services during Games. }\end{array}$ \\
\hline Some 30 other NSW Government Depts & & See the following website for more information about the organisations, \\
\hline and local government areas & & $\begin{array}{l}\text { their roles and general access provision: } \\
\text { Http://www.gamesinfo.com.au/ac/index.html }\end{array}$ \\
\hline
\end{tabular}

The organisation that was charged with the greatest degree of disability and access planning was OCA. This was because OCA oversaw the planning, design, construction and operation of all Games venues and the common domain. OCA's responsibility extended to developing a sustainable long-term plan for the venues for betterment of the people of NSW. SOCOG and SPOC had the major responsibilities for Games 
information, ticketing and the operation of the Games for their duration. The operational partnership established by SOCOG and SPOC alleviated many of the transitional problems that occurred between the Olympic and Paralympic Games in 1996 at Atlanta (Heath 1996). ORTA's role as transport coordinator was critical within the context of the NSW transport system. Other NSW government departments and local government areas had important roles to play in facilitating the 'Sydney experience' of the Games. Critical elements of these bodies will be discussed in relation to how their actions were perceived from a disability perspective.

Disability and access are not issues isolated to the Games. The process for inclusion of these issues was dependent on the human rights, environmental planning and building frameworks applicable in the country of the host City. Under the Commonwealth Disability Discrimination Act, 1992 (DDA), and associated state anti-discrimination legislation (Australia is a Federation of states with 3 levels of government), it is illegal to discriminate against a person on the grounds of disability. In NSW planning, development and construction must comply with amongst other legislation and policy: the Environmental Planning and Assessment Act, 1979 (NSW); the Local Government Act, 1993 (NSW); Building Codes of Australia; and the referenced Australian Standards for Access and Mobility (AS 1428 Parts 1 and 4; AS 1735.12; and AS 2890.1). As with most legislation their usefulness is only as good as the political will to implement them, and in the case of disability discrimination, it is only as good as the individuals and organisations willing to take action when discrimination occurs. This is because the DDA is complaints based legislation that seeks conciliation before the instigation of 
Federal Court action (see Jones and Basser Marks 1999; Handley 2001). Some of the critical disability and access issues of hosting the Games will now be discussed.

\section{CRITICAL ISSUES}

\section{Accessibility of the Urban Domain}

Sydney was planned and constructed in an ad-hoc fashion since European invasion in 1770 and subsequent settlement 1788 (Spearritt and DeMarco 1988). As such, Sydney is a mix of accessible and inaccessible areas. Apart from the Games precincts, the focus of public events took place in six largely accessible Live Sites (SOCOG 2000b) in Sydney's Central Business District (CBD). Many of these areas underwent major streetscape refurbishment as part of the Sydney City Council (SCC) Living Cities program (SCC 1994). Living Cities aimed to revitalise the street life of the Sydney CBD. However, SCC had been at the centre of a number of access controversies surrounding their streetscape refurbishment program (Southgate 1999). The SCC's attitude and behaviour led to the Physical Disability Council of NSW and People with Disabilities NSW Inc. (two peak disability organisations in NSW) taking three separate DDA complaints cases against the SCC (Horin 1999b). The complaints involved 'street improvements' that did not meet the Australian Standards for access and mobility (Standards Australia 1992a; 1992b; 1998) and included:

- $\quad$ kerb cuts that prevented wheelchair users from accessing footpaths;

- kerb heights that subsequently hindered access to the newly introduced low floor accessible buses;

- Installation of street scape furniture (benches, phone booths etc) that impeded people with vision impairments access of the city streets; and 
- Removal of an accessible overpass connecting a car parking station to a government building housing a range of services for people with disabilities (Horin 1999b; Southgate 1999; HREOC 2001).

As such, the accessibility of the urban domain in Sydney remained problematic for people with mobility and vision impairments.

\section{Access at the Games}

Generally, the OCA planning processes delivered an accessible Games experience through the planning, design, development and operations of the venue precincts. A review of planning processes for access and disability issues has been undertaken elsewhere (S. Darcy 2001a). Importantly the planning processes were designed to incorporate people with disabilities and disability organisations through the establishment of the Olympic Access Advisory Committee. The Committee was an essential part of the access planning process established in conjunction with the OCA Access Guidelines (OCA 1998a). However, the different perspectives held by members of the Committee led to heated debate over the meaning of access for projects and the degree to which the feedback provided by the Committee was used. Further, some members of the Committee felt that OCA's consultation process required greater leadtime for consideration of complex access issues. The planning processes were evaluated through an extensive series of test events designed to improve the operational planning for the Games. Many changes were made to disability and access provisions prior to the Games commencing (D. Hughes 1999; S. Darcy 2001). 
The experience gained by these test events were communicated to people with disabilities through the publication of the Sydney 2000 Access Guide to the Olympic and Paralympics Games (OCA 2000). Yet as with any mega event where 500,000 people were on-site at the Homebush precinct on a day-to-day basis access issues were bound to arise. OCA (2001) had put in place a range of operational plans to address these issues. A major concern for the accessibility of the Games was the delay in distributing the Access Guide by SOCOG. These were to have been distributed by SOCOG with the tickets for the Olympics but this was not done until a week after the Olympics had begun. This was further exacerbated by the lack of communication about the Access Guide to the disability community.

The Olympic and Paralympic Disability Advocacy Service (OPDAS) identified that over the Games period there were access problems with the shuttle services from the main transport drop-off points, spectator services, the wheelchair loan service and general physical access issues (OPDAS 2000:5). A major issue related to training for shuttle bus drivers, and spectator service volunteers about pick-up and drop-off arrangements. This was compounded by misinformation about essential services and facilities that led to inconvenience being experienced by people with disabilities and others with mobility issues through the greater distances that needed to be covered from the secure drop-off points to the venues.

The wheelchair loan service for older people and those with temporary disabilities at the Homebush precinct had teething problems that were addressed by the end of the first week of the Games through a better operational management process and the purchase 
of additional wheelchairs. The physical access issues were similar to those noted for the test events such as lack of signage, and inaccessible paths of travel. OPDAS (2000:6) noted that OCA responded to each of their specific complaints and provided solutions and operational changes to accommodate better management of those issues over the remainder of the Games (OCA 2001). One of the access successes was a series of audio and visual practices that were put in place to enhance the common domain and spectator experiences for people with vision and hearing disabilities (OCA 2001).

\section{Transport to the Games}

History has shown that the success of any host City's Games was dependent on transport due to the vast numbers of spectators that must be moved each day (Cashman and Hughes 1999; Toohey and Veal 1999). ORTA was established to coordinate this role and move and estimated 500,000 people a day to and from the sites (Wainright 2000). Public transport is essential for community participation and citizenship. Sydney historically has not had a public transport culture with the motor vehicle being a major influence on public policy discourse. Few areas of Sydney are well served by public transport, the exceptions being the Eastern suburbs and suburbs on the City Rail network. These general public transport issues are compounded by a public transport system that has not been inclusive of people with disabilities (Downie 1994). Transport for the Games had to operate within the confines of a largely inaccessible Sydney public transport system. Each component of this system is now examined prior to a review of complaints lodged during the Games period. 
Homebush has an Easy Access railway station for handling large numbers of the general public and has model access provisions. However, at the time of the Games only $7 \%$ of stations on the City Rail network were Easy Access stations (CityRail 2001). This was compounded by a system of ingress and egress from trains that consistently left people with mobility disabilities stranded on stations or carriages waiting for ramps or for staff to escort them through the labyrinth of access tunnels. Other people with disabilities are disadvantaged by inaccessible ticketing machines, lack of tactile indicators, absence of voice information systems and poor textual display systems (No Author 1999a; 1999b; Physical Disability Council of Australia 1999b).

The NSW State Transit Authority (STA) had increasingly purchased accessible low floor buses after DDA complaints cases in 1995 (HREOC 2001). As only 18 percent of the STA fleet were accessible, fully accessible services were restricted to a few select routes. This was further compounded because private operators had been resisting the implementation of low floor accessible buses (Todd 1999) and it was a consortium of these operators, through Bus 2000, who won the contract to service the Games routes. It had been estimated that only 1 percent of private operators' fleets in NSW are accessible. This was despite the Human Rights and Equal Opportunity Commission (HREOC) rulings in 1995, the progress on the DDA Draft Transport Standards and continuing pressure by the disability community (Corcoran 2001).

An inaccessible public transport system meant that people with disabilities were reliant upon either private transport, rented vehicles or the Sydney taxi service. The Sydney accessible taxi system has a range of well documented problems (Folino 1999). This 
includes taxis being consistently late for bookings (1-3 hours is not uncommon), not enough vehicles, drivers of vehicles who choose not to pick up passengers with disabilities, and lack of availability at night (Folino 1999). OCA and ORTA rightly identified all these transport issues as a major challenge to ensure that the needs of people with disabilities were identified and appropriately addressed. They specifically targeted the issues of staff training, increasing the number and consistency of accessible transport routes.

One of the highlights of the Games was the relative operational success of the public transport service. In particular the rail system operated without complaint. However, OPDAS (2000) documented concerns of people with disabilities using the regional bus services. These largely stemmed from the lack of planning to provide accessible buses by Bus 2000. Further, there were successful complaints actions by a number of organisations and people with disabilities to HREOC (2001) restricting the contracting of accessible buses from other states where services to people with disabilities would have been adversely affected (No Author 2000; Roberts 2000). The outcome of this poor planning was restricted services on the Games bus routes for people with disabilities. For example, all Games ticket holders got free public transport to the Games, available every 5 minutes on Games’ routes. However, accessible buses were only available every two hours and on some days not at all (OPDAS 2000). There were also uncertainties about the departure and return times of these services.

The operational changes to improve these problems involved the establishment of a hotline number that would organise one of the Sydney accessible taxis and meet their 
costs. This did not prove efficient as people were unaware of the service, the phone number was not widely known, and the accessible taxis have a range of systemic inefficiencies that caused long delays for those using the service (OPDAS 2000:5). OPDAS noted that during the Paralympics these issues were solved by the provision of 500 on-site parking spaces for people with Roads and Traffic Authority Mobility Parking Scheme Permits. No parking was allowed on-site during the Olympics.

Air travel has been identified as an area that requires significant improvement for people with mobility disabilities (Downie 1994; Darcy 1998). Sydney’s domestic and international airports, together with the Games official air carrier, had undergone significant infrastructure improvements in the lead up to the Games. Staff had been provided with disability awareness training to prepare them for the arrival and departure of 6,000 athletes and officials for the Paralympics (Israel 2000). However, air travel remains problematic due to aircraft design, international air regulations and lack of access to onboard sanitary facilities.

\section{Ticketing and Information}

Ticketing controversies plagued SOCOG generally, and there were a number of major ticketing issues from a disability perspective. These issues originated with the Official Olympic Games Ticket Book (SOCOG 1999). The book had a section of frequently asked questions, where one stated,

\section{I am confined to a wheelchair. Will I miss out on the Games?}


No. Provision is being made for disabled spectators to attend any session of the Olympics (SOCOG 1999:7).

To begin, the language used was ableist and does not reflect the way people with disabilities want to be represented. For example, a person is not confined to a wheelchair but the wheelchair is a mobility-liberating device that enhances community participation. This statement reinforces stereotypes of people with disabilities by nondisabled professionals and contravenes Australian media guidelines on representing disability (Hume 1994). Operationally the process of allocating seats for people with disabilities left more unanswered questions than answered questions. Each line of the application form had a box to be ticked if accessible tickets were required. However, no details of the dimensions of access were noted (i.e. mobility, vision, hearing or cognitive). It was not surprising that 25 percent of OPDAS (2000) complaints were for inappropriately allocated tickets for people with disabilities.

These complaints involved people who required accessible or enhanced seating but were issued with tickets for inaccessible seating (OPDAS 2000:4). SOCOG had instituted a process for reconciling these problems but the process itself was flawed with people not being contacted by SOCOG to replace tickets. Those people that were contacted by SOCOG were required to go to the SOCOG head office at Broadway in central Sydney, queue with other ticket holders to have their tickets replaced. These queues were up to 8 hours long and impossible for people with mobility or fatigue related disabilities to negotiate. Despite the representations of OPDAS and OCA, SOCOG insisted that there was no alternative way of replacing tickets. These practices were clearly discriminatory but were not resolved until a few days before the Olympic 
Games (OPDAS 2000:4) and caused a great deal of unnecessary distress for those inconvenienced.

SOCOG had a number of DDA complaints cases brought against them for ticketing and information issues. The most publicised of these complaints were brought by Bruce Maguire, a blind man, who wished to independently access the ticket book in alternate formats and to browse the official website of the Games (Maguire v SOCOG (Ticket Book) [1999]; Maguire v SOCOG (Internet) [2000]; Bryan 1999; Horin 1999a). There was no greater signifier of SOCOG's approach to disability issues than these cases where SOCOG firstly refused to comply with HREOC and Federal Court orders, and secondly, used the legal system to avoid compliance until after the Games were over (Horin 1999a; Jackson 2000a; 2000b).

The other cases involved wheelchair users. The first, involved an attendant ticket refund because it was found to be discriminatory against people with high support needs who required assistance to attend the Games (Gregory 1999). The second, where wheelchair users were restricted to ordering a block of 3 tickets, 1 wheelchair ticket and two nondisabled tickets (HREOC 2001). No other group in the community faced a restriction on block ticket booking. The third involved obstructed wheelchair sight lines at the tennis venue that did not provide equality of access for wheelchair users (HREOC 2001). 


\title{
Volunteers
}

The Games period required the involvement of 50,000 volunteers. Disability organisations identified the tremendous strain that was placed on their volunteer resources because of the Games drive for volunteers. SOCOG was offering volunteers a range of extrinsic incentives to join the volunteer program that disability organisations could not to hope to match. As F. Darcy (2001a:16) stated,

\begin{abstract}
Olympic volunteers received free uniforms, transport to and from venues, meals, tickets to either a dress rehearsal of the opening ceremony or a morning athletics session, Olympic pins and entry into a raffle for prizes including trips to IOC headquarters in Lausanne, Switzerland and Holden cars. There was also a tickertape parade held in their honour. However, very few organisations working with volunteers have the resources to provide such recognition and rewards to their volunteers beyond perhaps the reimbursement of their expenses.
\end{abstract}

This drain on the volunteer workforce was of particular concern to disability organisations where current government cutbacks had further eroded these organisations ability to provide basic services to their members (Cumming 1999; Horin 2000). Many of these and other cutbacks in government funding had been linked to increased expenditure by the NSW State Government on the Games. As Fallon (1999) noted, some disability organisations saw the Games period as a time for protest in much the same way that indigenous groups did.

Two other volunteer issues arose as acts of direct discrimination on the grounds of disability against volunteers. The first was the rejection by SOCOG of an applicant to work as a volunteer because they had a disability (OPDAS 2000:7). The second 
involved a volunteer with a mobility disability seeking reimbursement of taxi fares because they were unable to access the free public transport offered other volunteers. Both these matters were resolved after OPDAS had referred the individuals involved to the Disability Discrimination Legal Centre for action under the NSW AntiDiscrimination Act.

\section{Raising Disability Awareness}

The Sydney Paralympic Games can claim a number of records -

- the most number of spectators to witness a Paralympic Games;

- the most number of tickets sold; and

- the Paralympic Opening Ceremony being the most watch television program in the history of the Australian Broadcasting Commission broadcasting.

Why was this so? Partly this can be attributed to the nature of the Games as an urban spectacle that provided a spectacular for those in Sydney to witness (see Debord 1994). The Paralympics followed the undoubted success of the Olympic Games, the party atmosphere and the 'psychic benefits' generated (Gare 2000). People enjoyed themselves tremendously and wanted to continue enjoying themselves. Further, there were another two groups of people who joined the party. Firstly, those who had left Sydney for the Olympics, and secondly, those who were anti the Olympics but supported the Paralympics as it was not perceived as a corporatised event.

SPOC had also undertaken a very successful Reaching the Community Program (SPOC 1998a) that targeted school children and seniors. This was important to weekday crowd numbers because unlike the Olympics, the Paralympics were not held during school 
holidays. The success of these programs was capitalised upon with marketing of the Paralympic Day Pass Ticket. The \$15 ticket allowed access to all events held on one day (SPOC 2000b). By marketing the tickets in this way it allowed the public a chance to sample all events.

Does the success of the attendance at the Paralympics equal improved disability awareness amongst the non-disabled public? The politicians and the media discussed this as one of the great outcomes of the Paralympics (Gare 2000; Gibson 2000; Higson 2000; The Editor 2000). Unfortunately, this will only be known anecdotally as no research was conducted to test this hypothesis before, during or after the Games. It was a lost opportunity. Anecdotally the group who had a positive formative experience on their perceptions of disability were school children. Some people with disabilities reported a difference in approach to them during the Games by school children, and in some cases adults (Stern 2001). However, previous research by Wilhite, Muschett, Goldenberg and Trader (1997) suggests that even school children involved in a Paralympic inclusive sports program may not have a positive attitude change towards people with disabilities.

The positive images of athletes with disabilities competing in sport was an empowering image (Stern 2001; Anonymous 2002) and one that challenged the stereotypes of disability that are portrayed in the media and film (Goggin and Newell 2001). The other group that the Games may have had a lasting awareness raising impact on was the volunteer workforce assigned to venue services and the Village as they all underwent disability awareness training (F. Darcy 2001). For the rest of the public this question 
remains unanswered. The danger from a disability perspective was that the image of the 'supercrip' elite athlete creates an unreal expectation amongst the non-disabled that there are no socially constructed barriers to people with disabilities participating in the community (Goggin and Newell 2001). This was exemplified by the elite athlete's attitude that if you want to do it you can, no matter what. This was a great attitude for an individual to have in a sporting contest but for the majority of people with disabilities this is not their lived experience of trying to participate in the community (Physical Disability Council of NSW 1999; OPDAS 2000).

\section{Mixed Messages}

Graeme Connor's Being Here was the official song of the Sydney 2000 Paralympic Games (SPOC 1999b). The song states,

\section{Being Here}

"We have walked along hard roads to be here but it hasn't hurt me none.

I've learnt a thing or two along the way.

Like winning isn't always being first across the line, as long as I do my best I'm winning every time.

(chorus)

Reach up, reach out, being here is what it's all about This time, this place, to fight the good fight and run the good race and then when it's all through I will be proud to stand here beside you proud to remember being here.

(chorus)

You have been my true companion all the way, no one else will ever know what it took for us to come this far. But there's no sweeter victory than making dreams come true so take my hand and let me share my finest hour with you.

(repeat chorus)

Those that came before us and those that are to come all join us in this moment for in spirit we are one. (repeat chorus)

(Panama Music Company/Randor Music Australia) 
Licensed courtesy of the Panama Music Company Pty Ltd. Graeme Connors appears courtesy of ABC Music (SPOC 1999b).

This song introduces broader issue of the representation of disability in the Games, and partly the mixed messages that SPOC were sending to the public via the athletes and the marketing of the Paralympics. Being Here presents a non-disabled, ableist and patronising image of the Paralympic experience and of disability generally. The message clearly seeks to evoke sympathy from the public for the inspirational performances of the disabled that had been linked with past Paralympics (Curtis 2000). It was this inspirational component that the majority of media focused on (Gibson 2000; The Editor 2000). While the media prioritises stories based on sensationalism and inspiration this was in contrast to the message that the athletes presented publicly when discussing their perspective on the Games - they are elite athletes (Chynoweth 2000; Anonymous 2002). It was very much to either win or fail as an elite athlete, not as Connor's states, 'Like winning isn't always being first across the line’. Competing for the sake of competing or Being Here seemed to have very little to do with the discourse of the Australian Paralympic Ambassadors or the promotional material from SPOC. For example, Holygrail: the Official Album of the Sydney 2000 Paralympic Games (SPOC 1999b), from which Being Here was from, presented songs selected by high profile Australian Paralympic athletes and presented their philosophy of competing at the Paralympics. The first two songs epitomised this hard-edged win at all attitude - Louise Sauvage, the Australian premier track athlete, No Second Prize (Jimmy Barnes), and Sandy Blythe, the Australian male basketball captain, selection of Holy Grail (Hunters and Collectors). 
These very Australian songs are undoubtedly about winning and not just competing. As such, the imagery of the Games presented diametrically opposed positions. One as the Australian Paralympians as highly trained elite athletes performing super human feats. The second from the SPOC marketing perspective that sought to evoke the sympathy of the non-disabled public to support the 'poor cripple' (Goggin and Newell 2001). This image was based on the public finding inspiration in 'the disabled' overcoming their ‘deficits’ through sporting participation and Being Here.

This perspective was epitomised by the words of the Mayor of the Paralympic Village, Tim Fisher, referring to the athletes as 'Bravehearts' (Evans, 2000). This term was viewed by the Australian Paralympians as patronising (O'Brien 2000) and led to a debate in the Sydney media about the perceptions of the Paralympics. The debate discussed the merits of Paralympians as elite athletes and not 'disabled people', the merit of the Paralympics as a 'true' sporting spectacle, and the language of disability (Hinds 2000; Keenan 2000).

In other ways the Sydney Games media images presented the totality of athletes with disabilities in athletic performance rather than the public relations head and shoulders shots previously associated with Paralympic sport reporting. The media were not shy in using images that may have been considered far too confronting only months before the Games. Although these images did exhibit a fascination with assistive technology of the Games athletic performances (Higson 2000) or as Meekosha (1999), succinctly expresses the 'Cyborgs' of disability. 


\section{Perceptions of Disability - Classification Systems and the Marketing of the Global}

Sports

One of the controversies of the Paralympics was the exposure of members of the gold medal winning Spanish intellectually disabled men’s basketball team as not having intellectual disabilities (Walker 2000). This incident highlighted the complexity of the disability classification systems of the Paralympics that was a major source of spectator confusion (Davis and Fererra 1996). The incident focused attention away from the emphasis on athletic performances and disability awareness onto a major scandal. As the media prioritises stories based on their sensational nature this incident received the widest post Games coverage.

The International Paralympic Committee (IPC) launched an investigation and reported on the intricacies of the Paralympic classification systems. The likely outcome may be the exclusion of people with intellectual disabilities from future Paralympics (IPC Investigation Commission 2001). The inclusion of people with intellectual disabilities had always sat uncomfortably with the new marketing orientation of the Paralympics as a global sporting spectacle rather than an event representing the diversity of disability sporting endeavour and a celebration of the sporting excellence of people with disabilities.

Spectator confusion was also due to the need to understand a complex system of multi classification competition in the Paralympics. The simple outcome of 'who won' a particular event was clouded in multi classification system races where ‘who won' may 
not have been known for several minutes. These complexities were discussed within the IPC and SPOC in the lead up to the Games (Rigas 2000). The new marketing orientation had also seen debate surrounding the inclusions of the non-disabled within wheelchair competition to improve competitiveness and the spectacle of competition. This raises questions as to the role and purpose of the Paralympics, the integration of elite disability sport within the Olympic Games and the Games as part of the global sport spectacular.

\section{Relationships of SPOC with the Disability Community}

Throughout the planning for the Paralympics there was an ongoing tension between athletes as elite sports people and disability pride. One anecdote from early in the planning was the then NSW Minister for Ageing and Disability, Mr. Ron Dyer, was asked by SPOC to give a speech on the impending Paralympic Games but he was asked not to mention the word disability in giving the address. This anecdote can be considered deeply disturbing for people with disabilities as it shows an organisation that was at odds with a foundation aspect of the Paralympics. There was no doubting that Paralympians are elite athletes but they are, by definition, elite athletes with disabilities.

SPOC undertook a number of initiatives in developing the support of the disability community. The SPOC Community Relations Manager coordinated a database of approximately 300 disability-related contacts that received information about the Games. SPOC ran a community Working Together workshop (SPOC 1998b) that invited along key members of the disability community. The purpose of the day was to 
'identify ways that the disability community and the SPOC can work together to make the Paralympic Games a success and to raise the profile of people with a disability in the community’ (SPOC 1998b). This was an initiative that heightened people's expectations of the likely involvement of the community in the lead up to the Paralympics. However, after this day little occurred beyond information provision to the disability community. SPOC did undertake other initiatives under the Reaching the Community Program. These included: National education program; Sports demonstrations; Rides 2000; and Partnerships programs.

The original Partnerships Programs included multicultural communities, service groups, local community events and disability groups (SPOC 1998a). Yet no partnership program was developed with disability groups. The revised Paralympics Fact Sheet omitted the mention of disability groups as part of the Partnership Programs (SPOC 1999a). A questionnaire was sent out to 200 disability organisations (membership unspecified) in mid 1999 to elicit information about ticketing options and topics for inclusion in a seminar to be held on access to the Games (SPOC 1999c). The Seminar took place on 29 June 2000 and provided information on those wishing to attend the Olympics and Paralympics (SPOC 2000a). This was well short of the earlier expectations of a partnership program between SPOC and the Sydney disability community (SPOC 1998a).

The Paralympic Pursuit and Paralympic Postcard Newsletters were a sound initiative to keep individuals and groups informed of all things Paralympic. However, as with the previously mentioned initiatives there was a major difference between informing and 
involving the community. People with disabilities were hearing about developments with the Paralympics but did not feel actively involved in the process. While SPOC was disseminating information about the Paralympics there was a feeling that the Paralympics were disassociated from the local disability community. For example, when SPOC had 'launches' of programs and events there was no effort to include representatives from the disability community to be part of the events. It was as if disability was the invisible part of the Paralympics. This aspect was a major concern for the disability movement. In effect, SPOC did comparatively less to develop the involvement of people with disabilities and disability organisations than it did to involve sponsors, school children and seniors.

As discussed in the previous sections on Raising Disability Awareness and Mixed Messages, SPOC's marketing strategy was to focus on the Paralympics as an elite sporting event (SPOC 1998b). At the same time this was a denial that the Paralympics was also a premier sporting event for people with disabilities. If the athletes did not have a disability then the event would not be taking place and they would not be competing. The marketing strategy of focusing upon the elite sporting performance was of an immense strategic marketing importance in trying to attract sponsorship. However, SPOC needed to recognise that there were different groups that they needed to market to and people with disabilities were one of them. To alienate this group from the process was regrettable. It would have been far more empowering if SPOC had engaged the disability community in the Paralympics in an active and emancipatory way rather than having the community sidelined as passive spectators. 
A signifier of these tensions was the invited address by two Paralympians to the NSW Parliament (Hansard 2000). Over the preceding eighteen months there had been a series of heated street protests by the disability community over a number of critical issues. These included the tendering out of group homes for people with intellectual disabilities, the funding crisis in Personal Aids for Disabled People and a rally in support of inclusive education opportunities (Cumming 1999; Fallon 1999; Horin 1999c; 1999d). The address to the NSW Parliament by the Paralympians was a case where the 'good news' of sporting endeavors were being used by government as propaganda to camouflage critical human rights issues in NSW (Horin 2000).

\section{LASTING LEGACY}

Mackay (2001:16) states,

Its certainly true that, at the time, many people believed the Games would change us forever. Six months on, though, I'm struggling even to recall what the changes were supposed to be.... But why search for more than you're ever likely to find? We have acquired some pleasant memories. Shouldn't we leave it at that?

In the history of the Australian disability movement did the Games contribute to a change in culture from a disability perspective? As the Executive Officer of the Disability Council of NSW states, 'It is my belief that Sydney in particular has benefited from the Olympics by way of infrastructure...The society may have got there eventually but it would be a long time before it happened without the Olympics’ (Byrne 2002:1). Further, those professionals involved in the planning of the venues, common domain and transport now know what is required to develop an inclusive planning process that has the potential for effective and efficient outcomes. One tangible outcome of the 
Games was the development of an on-line access resource for planning accessible environments and events. The resource has incorporated the Games's planning, development, construction and operations experiences for disability and access (http://www.oca.nsw.gov.au/access/html/default.cfm).

As Stern (2001) noted, there was anecdotal evidence of increased disability awareness amongst the community, particularly school children. While there was no research to document whether this translated into improved community attitudes to disability the Games may have provided an opportunity to build upon this goodwill. Whether disability advocacy groups and service providers have been strategic enough to capitalise upon this opportunity is another question.

Yet even after these successes there was pessimism within the disability community about the lasting legacy of the Games. In particular, cynicism existed about the number of politicians willing to support the Games but normally unwilling to discuss disability issues, let alone demonstrate an understanding of them. Others questioned the level of spending on the Games, the level of unmet need in the disability community and the loss of funding to a range of disability programs in the years leading up to the Games (Horin 2000).

What was overlooked was that most of the inclusive practices could not have been delivered without a human rights framework. Yet the DDA and the inclusive practices discussed in this paper, were founded on the blood, sweat and tears of the Australian disability community. Where would the level of accessible public transport and venues 
be without individuals like Elizabeth Hastings (Hastings 1997; Adams 2000) and Ian Cooper (Druett and Bately 2000), and disability advocacy groups like People with Disabilities Inc., Physical Disability Council of Australia, Blind Citizens Australia, Women with Disabilities Australia, the Deafness Forum, National Council on Intellectual Disability and alike who used the DDA, advocacy and political pressure to bring about social change. The Games did not bring these social changes, the Games were made better by the social changes instigated by people with disabilities. These actions were supported by the ongoing involvement of people with disabilities and disability advocacy organisations on committees, in consultations, lobbying and advocacy that occurred in the lead up to the Games (S. Darcy 2001b).

As documented in this paper organisations like SOCOG were still able to blatantly discriminate against people with disabilities, disregard the rulings of HREOC and the Federal Court, and be deliberately obstructive in their process for dealing with disability and access issues (Jackson 2000a). SOCOG's approach to disability and access issues was radically different to OCA. This could be attributed to the organisational culture of SOCOG due to its sunset clause, the lack of internal disability and access expertise, and the pressure of planning the Games. This led to disability and access issues being marginalised (OPDAS 2000). It wasn't until 2000 when the operations of OCA and SOCOG were amalgamated that disability and access issues began to be addressed systematically. A greater part of OCA's commitment to these issues can attributed to the OCA Director David Richmond, and the Manager of Co-ordination, Jane Woodruff, who both had disability experience from past positions in third sector disability organisations and senior roles in the NSW Government. 
For many people with disabilities these changes have had little impact on their day to day lives. As the Executive Officer of the Disability Council of NSW notes, 'Sadly, there is still an unacceptable waiting list for very necessary personal care services for people with significant disabilities in NSW' (Byrne 2002:2). In the years since the Games a number of issues have arisen that once again signal a segregated rather than universal approach to disability citizenship in the city of Sydney, the state of NSW and Australia generally. These include:

- Decreasing levels of funding for housing and increasing levels of homelessness and incarceration of people with intellectual disabilities (Murphy 2000);

- Continued delays to ratifying the DDA Draft Transport Standards instigated by the transport lobby (HREOC 2001);

- The Ageing and Disability Dept. of NSW attempt to de-fund peak disability bodies from systemic advocacy (Hansard 2001);

- Disability Services Commission report into the deaths of 211 people with disabilities in institutional care (Disability Services Commission (NSW) 2001);

- HREOC's Public Inquiry into wheelchair accessible taxis (HREOC 2001); and

- Sydney City Council disbanding its Access Committee (Laffan 2002).

\section{CONCLUSION}

Some twenty years after the IYDP Sydney hosted an exceptional Games. This included a Paralympics that achieved many records in terms of spectators, ticketing and media 
coverage where an elite disability sporting event became the focus of Sydney. The conventional wisdom was that the Games delivered to the host city community of people with disabilities a lasting legacy of accessible infrastructure, a raised level of disability awareness and an improved position in society. Yet this paper has demonstrated that the Games may have increased the speed of social change for accessible infrastructure but these successes were borne from the effort of people with disabilities to bring about the social change through the potential offered by the human rights frameworks. The human rights framework was kept honest by their diligence and participation in the planning process. Further, this was assisted by disabled and nondisabled individuals within government who championed these issues to ensure their implementation. It was only through the combination of these social relations that the accessible Games’ experience was delivered.

Whether the Paralympics has raised the level of disability awareness in the community and led to an improved position in society for people with disabilities remains unanswered. However, the Games showed that if government and the private sector had the will then they could deliver an inclusive experience. This experience was the first time that many people with disabilities could share a common community experience whether as spectators, volunteers, employees or participants. From a planning perspective whether it was venues, common domain, customer service or transport it has been shown what people with disabilities should expect every day of our lives and not just when the world was watching. Yet for many people with disabilities in NSW the Games has had no material impact on their lives, they live in a continued state of unmet needs and will continue to do so long after the Games are just a memory. 


\section{REFERENCES}

Case Law

Maguire v SOCOG (Internet) [2000], Unreported (HREOC No H 99/115).

Maguire v SOCOG (Ticket Book) [1999], Unreported (HREOC No H 99/115).

\section{Legislation}

Disability Discrimination Act, 1992 (Commonwealth)

Environmental Planning and Assessment Act, 1979 (NSW)

Local Government Act, 1993 (NSW)

Building Codes of Australia (Commonwealth); and the referenced

Australian Standards for Access and Mobility (AS 1428 Parts 1-4 amongst others)

\section{Websites for further information}

Disability Council of NSW http://www.discoun.nsw.gov.au/

Human Rights and Equal Opportunity Commission - Human Rights

http://www.hreoc.gov.au/disability_rights/index.html

OCA Achieving Access http://www.oca.nsw.gov.au/access/html/default.cfm

\section{References}

ADAMS, P. (2000) High hurdles for able-bodied. The Weekend Australian, Sat 21 October, pp. 31.

AUSTRALIAN BUREAU OF STATISTICS (2000) Australia Now (Canberra, Australian Bureau of Statistics).

ANONYMOUS. (2002) Elitist and Proud of It - An interview with Greg Hartung, President of the Australian Paralympic Committee. Disparity Magazine, Winter, pp. http://www.accessibility.com.au/news/articles/elitists_hartung.htm. 
BRYAN, M. (1999) Games alleged to be out of sight The Manly Daily, December 1112, pp. 20.

BYRNE, K. (2002) Sydney 2000 Games legacy (Disability Council of NSW, Sydney) pers comm. to S. Darcy, email, 20 December

CASHMAN, R., \& HUGHES, A. (1999) Staging the Olympics: the event and its impact (Sydney, UNSW Press).

CHYNOWETH, C. (2000) Wheel power, Daily Telegraph, April 1, pp. 36-37.

CITYRAIL (2001) Accessing CityRail: An easy guide to accessible services (Sydney, City Rail).

COOPER, M. (1999), The Australian Disability Rights Movement lives. Disability \& Society, 14(2), pp. 217-226

CORCORAN, M. (2001) Disability Discrimination Act Standards - What's the Delay? in: SRDRN (Eds) Conference proceedings of Disability with Attitude: Critical Issues 20 years after International Year of Disabled Persons, (Parramatta Campus, University of Western Sydney) February 16-17 2001, pp. 57-66.

CUMMING, F. (1999) Disabled cuts 'obscene' The Sun-Herald, September 12.

CURTIS, O. (2000) Finding inspiration, Sport health, 18(3), pp. 24-26.

DARCY, F. (2001a) "The Best Ever" - Volunteering at the Sydney 2000 Olympics Australian Journal of Parks and Leisure, 4(2), pp. 15-17.

DARCY, S. (1998) Anxiety to Access: The tourism patterns and experiences of New South Wales people with a physical disability. (Tourism New South Wales: Sydney).

DARCY, S. (2001b) A Games for Everyone?: Planning for Disability and Access at the Sydney 2000 Games Disability Studies Quarterly, 21(3), pp. 70-84.

DAVIS, R., AND FERRARA, M. (1996) Athlete classification: An explanation of the process. Palaestra, 12(2), pp. 38-44.

DAVIS, T. (1996) The Most Accessible Games. Paraplegia News, 50(11), pp. 40-42.

DEBORD, G (1994) The society of the spectacle (Société du spectacle). (New York, Zone Books)

DISABILITY SERVICES COMMISSION (NSW) (2001) Disability, death and the responsibility of care (Sydney, Disability Services Commission).

DOWNIE, A. (1994) Target 2015: A Vision for the Future - Access to transport in Australia for all Australians (Disability Advisory Council of Australia).

DRUETT, F. \& BATELY, P. (2000) Obituary - Ian 'Mini' Cooper Disability Activist 1954-2000 Sydney Morning Herald, May 17, pp. 24.

EVANS, M. (2000) Fisher puts on a brave face The Sydney Morning Herald, October 18, pp. 2.

FALLON, L. (1999) Disabled protest: Groups threaten to focus on the games The Manly Daily, September 9, pp. 2.

FOLINO, B. (1999) Taxis and People with a Disability: Issues for Government and Industry (Sydney, Disability Council of NSW).

GARE, S. (2000) Awareness is the aim of the Games The Weekend Australian, 14-15 December 14-15, pp. 22.

GIBSON, M. (2000) Winners in the game of life The Daily Telegraph, October 18, pp. 33. 
GOGGIN, G. \& NEWELL, C. (2001) Crippling Paralympics? Media, Disability and Olympism Media International Australia, 97(November 2000), pp. 71-83.

GREGORY, P. (1999) Games ticket win to quadriplegic The Age, August 4.

HANDLEY, P. (2001) 'Caught Between a Rock and a Hard Place': Anti-discrimination Legislation in the Liberal State and the Fate of the Australian Disability Discrimination Act. Australian Journal of Political Science, 36(3), pp. 515528.

HANSARD (2000) Paralympic Address to Parliament by Hamish MacDonald \& Julianne Adams (Sydney, NSW Government). Available: http://www.parliament.nsw.gov.au/prod/web/PHWeb.nsf/Hansard?OpenFrameS et Last [2000, 12 Dec].

HANSARD (2001) Disability Advocacy Report (Sydney, NSW Government). Available:

http://www.parliament.nsw.gov.au/prod/web/PHWeb.nsf/Hansard?OpenFrameS et Last [2001, 1 August].

HASTINGS, E. (1997) FounDDAtions: Reflections on the first five years of the Disability Discrimination Act in Australia. (HREOC: Sydney).

HEATH, J. (1996) 1996 Atlanta Paralympic Games. Link, 5(4), pp. 16-23.

HIGSON, R. (2000) The enabling games The Weekend Australian Magazine, November 11-12, pp. 50-52.

HINDS, R. (2000) Sense and sensibilities: the delicate balance of reporting Paralympics The Sydney Morning Herald, October 15, pp. 80.

HORIN, A. (1999a) Blind man wins a Games chance The Sydney Morning Herald, June 26.

HORIN, A. (1999b) CBD turns back on' disabled The Sydney Morning Herald, June 5, pp. 22.

HORIN, A. (1999c) Homes sell-off angers disabled tenants The Sydney Morning Herald, September 8, pp. 8.

HORIN, A. (1999d) Scarlett's victory a warning to schools: don't shut out disabled The Sydney Morning Herald, July 22, pp. 3.

HORIN, A. (2000) After the Paralympics, priorities The Sydney Morning Herald, November 2, pp. 41.

HUGHES, A. (1999a) The Paralympics, in: R. CASHMAN \& A. HUGHES (Eds), Staging the Olympics: the Events and its Impact (Sydney, UNSW Press).

HUGHES, D. (1999b) Easter Show Access Provisions (Sydney, Australian Quadriplegic Association).

HUMAN RIGHTS AND EQUAL OPPORTUNITY COMMISSION (2001) Disability Rights Website (Website HREOC). Available: http://www.hreoc.gov.au/disability_rights/index.html Last [2001, 20 June 2001].

HUME, J. (1994) Media Guidelines (Sydney, Disability Council of NSW).

INTERNATIONAL PARALYMPIC COMMITTEE INVESTIGATION COMMISSION (2001) Summary Report of the IPC Investigation Commission on INAS-FID Allegations at the XIth Paralympic Summer Games Sydney 2000 (Salt Lake City, International Paralympic Committee).

ISRAEL, J. (2000) It might not be plane sailing but it is better than before. Sydney Morning Herald, 18 April, pp. 27. 
JACKSON, A. (2000a) SOCOG refuses to play ball with sightless man The Sydney Morning Herald, August 29, pp. 7.

JACKSON, A. (2000b) Web case moves to court site The Sydney Morning Herald, July 4, pp. 23.

JONES, M., AND BASSER MARKS, L. A. (1999) Disability rights and law in Australia. in M. Jones and L. A. Basser Marks (Eds.), Disability, Divers-ability and Legal Change. (Kluwer Law International: Great Britain) pp. 189-208

KEENAN, C. (2000) Running off at the mouth The Sydney Morning Herald, October 18, pp. 19.

LAFFAN, M. (2002) Sydney Mayor Winds Up Access Committee Accessibility.com. Available: http://www.accessibility.com.au/news/articles/access_committee.htm Last [2002, 19 July].

MACKAY, H. (2001) One for the album The Sydney Morning Herald, March 31, pp. 16 (Spectrum).

MEEKOSHA, H. (1999) Superchicks, Clones, Cyborgs, and Cripples: Cinema and Messages of Bodily Transformations Social Alternatives, 18(1), pp. 24-28.

MURPHY, D. (2000) Out of Sight, Out of Mind The Sydney Morning Herald, April 1, pp. 2-6.

NEWELL, C. (1996) The disability rights movement in Australia - a note from the trenches. Disability \& Society, 11(3), pp. 429-3432.

NEWELL, C. (1999) Encountering Oppression: the Emergence of the Australian Disability Rights Movement. Social Alternatives, 18(1), pp. 47-52.

NO AUTHOR (1999a) Rail-banned Paralympian issues Games warning The Sun Herald, November 11, pp. 28.

NO AUTHOR (1999b) Wheelchair access row The Sydney Morning Herald, November 8, pp. 10.

NO AUTHOR (2000) Disabled unhappy as buses go North The Sydney Morning Herald, June 19, pp. 5.

O'BRIEN, J. (2000) Wheelchair athletes don't want your sympathy The Sydney Morning Herald, October 19, pp. 5.

OLYMPIC \& PARALYMPIC DISABILITY ADVOCACY SERVICE (2000) Final Report to the Department of Family and Community Services (Sydney, Commonwealth Department of Family and Community Services).

OLYMPIC CO-ORDINATION AUTHORITY (1998) Access Guidelines (2nd ed.) (Sydney, Olympic Co-ordination Authority).

OLYMPIC CO-ORDINATION AUTHORITY (2000) Sydney 2000 Access Guide to the Olympic and Paralympic Games (Sydney, Olympic Co-ordination Authority).

OLYMPIC CO-ORDINATION AUTHORITY (2001) Accessible Operations Post Game Report - Sydney 2000 Olympic and Paralympics Games. (Sydney, Olympic Co-ordination Authority)

PHYSICAL DISABILITY COUNCIL OF AUSTRALIA (1999a) We Will Ride Campaign - The argument for DDA Accessible Public Transport Standards (Sydney, Physical Disability Council of Australia). Available: www.pdc.org.au Last [1999, 20 November 1999]. 
PHYSICAL DISABILITY COUNCIL OF NSW (1999b) Position Papers (Sydney, Physical Disability Council of NSW).

RIGAS, A. (2000) Structural And Directional Approaches For The Further Development Of The Paralympic Movement Unpublished Masters Project, (Sydney, University of Technology, Sydney).

ROBERTS, G. (2000) Bus Shortages for Disabled Games The Sydney Morning Herald, July 7, pp. 5.

SOUTHGATE, L. (1999) Sydney must lift its game on disabled access The Australian, April 26, pp. 34.

SPEARRITT, P. \& DEMARCO, C. (1988) Planning Sydney's future (Sydney, Allen \& Unwin, New South Wales. Department of Planning).

STANDARDS AUSTRALIA (1992a) AS 1428.2 - 1992 Design for access and mobility. Enhanced and additional requirements - Buildings and facilities (Homebush, Standards Australia).

STANDARDS AUSTRALIA (1992b) AS 1428.4 - 1993 Design for access and mobility. Tactile ground surface indicators for the orientation of people with vision impairment (Homebush, Standards Australia).

STANDARDS AUSTRALIA (1993) AS 2890.1 - Parking Facilities: Off Street parking (Homebush, Standards Australia).

STANDARDS AUSTRALIA (1999) S 1735.12 - Lifts, escalators and moving walkways: Facilities for persons with disabilities (Homebush, Standards Australia).

STANDARDS AUSTRALIA (1998) AS 1428.1 - Design for access and mobility. General requirements for access - new buildings (3rd ed.) (Homebush, Standards Australia).

STERN, D. (2001) Editorial - What is the legacy of the Paralympics? Quadrangle: Official Australian Quadriplegic Association, 16(4), pp. 2-3.

SYDNEY CITY COUNCIL (1994) Living Cities (Sydney, Sydney City Council).

SYDNEY ORGANISING COMMITTEE FOR THE OLYMPIC GAMES (1999) Official Olympic Ticket Book (Sydney, SOCOG).

SYDNEY ORGANISING COMMITTEE FOR THE OLYMPIC GAMES (2000a) Official Sydney 2000 Website (Sydney, SOCOG). Available: http://www.sydney.olympics.org/eng/ Last [2000, August].

SYDNEY ORGANISING COMMITTEE FOR THE OLYMPIC GAMES (2000b) Sydney 2000 Official Spectator Guide (Sydney, SOCOG).

SYDNEY PARALYMPIC ORGANISING COMMITTEE (1998a) Fact Sheets (Sydney, SPOC).

SYDNEY PARALYMPIC ORGANISING COMMITTEE (1998b) Working Together Workshop Notes (Sydney, SPOC).

SYDNEY PARALYMPIC ORGANISING COMMITTEE (1999a) Fact Sheets (Sydney, SPOC).

SYDNEY PARALYMPIC ORGANISING COMMITTEE (1999b) HOLYGRAIL: The Official Album of the Sydney 2000 Paralympic Games (Sydney, SPOC in conjunction with Michael Chugg and Thomas Heymann).

SYDNEY PARALYMPIC ORGANISING COMMITTEE (1999c) Questionnaire for June 2000 Seminar Results Letter (SPOC: Sydney). 
SYDNEY PARALYMPIC ORGANISING COMMITTEE (2000a) Information Kit on Access \& the Games (Sydney, SPOC).

SYDNEY PARALYMPIC ORGANISING COMMITTEE (2000b) Sydney 2000 Paralympic Games official program 18-29 October 2000 (Melbourne, News Custom Publishing).

THE EDITOR (2000) Inspiring Games The Sydney Morning Herald, 18 October, pp. 33.

TODD, K. (1999) The Impact of the Disability Discrimination Act (Hobart, Australian Bus and Coach Association Conference).

TOOHEY, K. M. \& VEAL, A. J. (1999) The Olympic Games: a social science perspective (London, CAB International).

WAINRIGHT, R. (2000) Moving Masses Sydney Morning Herald, 20 June, pp. 2527.

WILHITE, B., MUSCHETT, C. A., GOLDENBERG, L., AND TRADER, B. R. (1997) Promoting inclusive sport and leisure participation: evaluation of the Paralympic Day in the Schools model. Adapted physical activity quarterly, 14(2), pp. 131146.

WALKER, J. (2000) Spain's Games shame Weekend Australian, 2-3 December, pp. 24-25. 